\title{
THE EFFECT OF MOTIVATION AND WORK ENVIRONMENT ON THE PERFORMANCE OF HOTEL EMPLOYEES, MURIA SEMARANG
}

\author{
Arta Adi Kusuma
}

Fakultas Ekonomi Universitas Negeri Semarang

\section{ARTICLEINFO}

Keywords:

Work Motivation

Work Environment

Performance

\begin{abstract}
The population in this study were all 115 employees of Hotel Muria Semarang. The sample was determined by proportional random sampling technique, with 53 respondents as respondents. The data collection method used is a questionnaire (questionnaire) and documentation method. The data analysis method used in this research is the percentage description analysis method and multiple linear regression. Based on the results of the study, it was obtained that the multiple linear regression equation $=23.857$ $+0.180 \mathrm{X} 1+0.94 \mathrm{X} 2$. By using SPSS 16 the results of the F test hypothesis show $\mathrm{F}$ count $=16,646$ with a significance value $=0.000<0.05$ which means H3 which reads "There is a significant influence of motivation and work environment on employee performance at Hotel Muria Semarang" is accepted. Meanwhile, from the partial hypothesis test ( $t$ test) it is obtained that the $t$ count of the motivation variable is 2,619 , the $t$ count of the work environment variable is 2,207 where the probability is less than 0.05 then the hypothesis is accepted. The coefficient of determination (Adjusted R2) is 0.376 , this means that $37.6 \%$ of the employee performance of Hotel Muria Semarang is influenced by motivation and work environment, while the rest is influenced by other variables that are outside the variables studied in this study. The conclusion is that motivation is in the good category, the work environment is in the good category, and the performance of the employees of Hotel Muria Semarang is in the good category. Motivation has an influence on employee performance with a contribution of $12.04 \%$. The work environment has an influence on employee performance with a contribution of $8.88 \%$. Motivation and work environment together have an influence on employee performance with a contribution of $37.6 \%$. Suggestions that can be given in this study are indicators of the need for security, namely the absence of a better future guarantee from the company. It is hoped that the need for security can be overcome, such as by having a pension fund after the work period is over or an old-age guarantee. The indicators of social needs are the lack of interaction between employees at work and the indifferent attitude between employees. It is hoped that social needs can be overcome by the company holding tours or recreation with employees so that relations between employees are closer, creating working groups for employees. From the work environment variables, the weakness in the lighting indicator.
\end{abstract}

Copyright (C) 2021 Journal of Economics.All rights reserved.

\section{is Licensed under a Creative Commons Attribution-NonCommercial 4.0
International License (CC BY-NC 4.0) \\ is Licensed under a Creative Commons Attribution-NonCommercial 4.0
International License (CC BY-NC 4.0)}

E-mail:

Artaadi91@gmail.com

\section{INTRODUCTION}

Performance is the result of work that can be achieved by a person or group of people in an organization, in accordance with their respective authorities and responsibilities, in an effort to achieve the goals of the organization concerned legally, not violating the law and in accordance with morals and ethics.[1]. Performance is influenced by several factors including the quantity of work that can be done by a person within one working day, quality in adherence to procedures and discipline, reliability in carrying out the required work with minimum supervision, attendance at work every day and according to working 
hours, and ability to work. together with others in completing assigned tasks and work so as to achieve maximum efficiency[2], [3].

Performance is influenced by many factors including individual factors and situational factors. Individual factors include attitudes, personality traits, physical traits, desires or motivations, age, gender, education level, cultural background, and other personal variables. Situational factors include social and organizational factors, physical and occupational factors. Social and organizational factors include organizational policies, types of training and supervision, wage systems and social environment. Physical and occupational factors, including: work methods, design and condition of work tools, determination of work space, and work environment[4]. Employee performance is influenced by salary, work environment, organizational culture, leadership and work motivation (motivation), work discipline, job satisfaction, motivation [5]. In this study, researchers examined motivation and work environment. If the motivation is good and the work environment is good, the resulting performance will also be good. Motivation is a factor that greatly determines performance. Motivation is an impulse, desire, desire and driving force that comes from humans to do or to do something[6]. So basically if the company wants to achieve optimal performance in accordance with the targets that have been set, the company must motivate employees so that employees are willing and willing to devote their energy and thoughts for the sake of work. The problem of motivating employees is not easy because in employees there are desires, needs and expectations that differ from one employee to another. So if management can understand motivational issues and overcome them, the company will get optimal employee performance in accordance with the specified standards[7], [8]

The work environment can create a binding working relationship between people in the environment. Therefore, efforts should be made so that the work environment must be good and conducive because a good and conducive work environment makes employees feel at home in the room and feel happy and excited to carry out their duties so that job satisfaction will be formed and from the employee's job satisfaction, employee performance will also increase [9], [10].

Paand basically there is already a good motivation and work environment at Hotel Muria Semarang, but there are still fluctuating presentations. In this case, there are still many employees who arrive late for work and do not come to work without or without a certificate.

The working environment of Hotel Muria Semarang, researchers know from initial observations, in security conditions the company pays special attention to the inspection of every guest who comes, requires employees who use motorbikes to wear helmets when entering the parking area for order and awareness of the importance of wearing a helmet. helmet when driving. Availability of vehicle parking space so that employees can relax at work. There is ventilation so that the air circulation in the room is always fresh.

\section{METHOD}

\section{PResearch population}

PThe population is a generalization area consisting of: objects/subjects that have certain qualities and characteristics determined by the researcher to be studied and then draw conclusions. The population used in this study were all employees of Hotel Muria Semarang, totaling 115 people.

\section{Research sample}

sample is part of the number and characteristics possessed by the population. Based on the calculations, the number of samples obtained is 53 out of 115 employees of Hotel Muria Semarang. To determine the sample in this study using proportional area random sampling technique, namely the sampling technique taken from each subpopulation which was taken randomly based on the proportion of the number of employees in each subpopulation.

\section{Research variable}

The research variable is the object of research or what is the point of attention of a study. The variables in this study consist of the independent variable $(\mathrm{X})$ and the dependent variable $(\mathrm{Y})$.

\section{Data Type}

The types of data in this study are:

1. Primary data

Primary data is data obtained from the first source both from individuals and individuals. This data is the result of filling out a questionnaire regarding motivation, work environment, and performance filled by employees of Hotel Muria Semarang.

2. Secondary Data

The Effect Of Motivation And Work Environment On The Performance Of Hotel Employees, Muria Semarang Arta Adi Kusuma 
Secondary data is used to complete the required data. Secondary data used in this study is the organizational structure of the employees of Hotel Muria Semarang.

\section{sourcer Data}

The data sources used in this research are only internal data sources. Internal data sources are data sources obtained from within the company or organization where the research is carried out. In this study, the internal data sources were employees of Hotel Muria Semarang. Internal data in the form of data points assessment of the work of employees, profile and organizational structure of Hotel Muria Semarang and answers to the results of filling out the questionnaire.

\section{Data collection method}

Data collection method is a method or method used by researchers to obtain data in a study. In this study the methods used to collect data are:

1. Questionnaire (questionnaire)

Questionnaire technique is a way of collecting data by distributing questions to respondents and respondents will provide responses to these questions. The selection of the questionnaire technique in this research is to obtain accurate data directly from the people who will be asked for data.

2. Documentation

Documentation technique is the collection of data and information through archives and documentation. To obtain the required supporting data from reliable sources, documentation techniques are used. Documentation technique is useful for obtaining data about the number of employees and data about the general description of Hotel Muria Semarang, and other supporting data.

\section{RESULTS AND DISCUSSION}

\section{Mywork antis}

Represents the resulting quantity expressed in terms such as number of units, number of completed activity cycles. The results of the descriptive analysis of the percentage of work quantity at Hotel Muria Semarang can be seen in the following table:

Table 1. Results of Descriptive Calculation of Work Quantity Indicators

\begin{tabular}{cccc}
\hline No. & Ffrequency & Pepercentage & Jaanswer \\
\hline 1 & 6 & $11.32 \%$ & Sadon't agree \\
2 & 43 & $81.13 \%$ & Sego \\
3 & 4 & $7.55 \%$ & Disagree \\
4 & 0 & $0.00 \%$ & Do not agree \\
5 & 0 & $0.00 \%$ & Sadon't agree \\
\hline Jumlah & 53 & $100 \%$ &
\end{tabular}

From the table above, the results of the research on the quantity of work as much as $81.13 \%$ agree, based on the total score of the work quantity indicator of 409 or $77.17 \%$ of the quantity of work included in the good category. It can be seen that most of the employees have completed a job that is better than the standard and in accordance with the targets set by the company.

\section{Mywork quality}

The quality of work is measured by the employee's perception of the quality of the work produced and the perfection of the task on the skills and abilities of employees. The results of the descriptive analysis of the percentage of work quality at Hotel Muria Semarang can be seen in the following table:

Table 2. Descriptive Calculation Results of Work Quality Indicators

\begin{tabular}{cccc}
\hline No. & frequency & percentage & answer \\
\hline 1 & 7 & $13.21 \%$ & Sadon't agree \\
2 & 44 & $83.02 \%$ & Sego \\
3 & 2 & $3.77 \%$ & Disagree \\
4 & 0 & $0.00 \%$ & Do not agree \\
5 & 0 & $0.00 \%$ & Sadon't agree \\
\hline Jumlah & 53 & $100 \%$ & \\
\hline
\end{tabular}


From table 3. above, the results of the work quality research as much as $83.02 \%$ agree, based on the total score of work quality indicators of 415 or $78.30 \%$ so the quality of work is included in the good category. It can be seen that most employees have good work quality such as being able to complete work on time Tomainstay

Reliability is the ability to perform the required work with minimum supervision. According to Zeithaml \& Berry in the Journal of Marketing (in Sudarmanto, 2009:14) reliability includes performance consistency and reliability in service; accurate, true and precise. The results of the descriptive analysis of the percentage of reliability at Hotel Muria Semarang can be seen in the following table.

Table 4. Descriptive Calculation Results of Reliability Indicators

\begin{tabular}{cccc}
\hline No. & frequency & percentage & answer \\
\hline 1 & 2 & $3.77 \%$ & Sadon't agree \\
2 & 33 & $62.66 \%$ & Sego \\
3 & 15 & $28.30 \%$ & Disagree \\
4 & 3 & $5.66 \%$ & Do not agree \\
5 & 0 & $0.00 \%$ & Sadon't agree \\
\hline Jumlah & 53 & $100 \%$ &
\end{tabular}

From table 4 above, the reliability research results as much as $62.66 \%$ agree, based on the total reliability indicator score of 361 or $68.11 \%$ so reliability is included in the good category. It can be seen that some employees have good work reliability such as accuracy in doing their work, but some employees also have good reliability so that superiors can try to improve it such as holding training and job development.

kehadiran

Attendance is the belief that you will come to work every day and according to working hours. The results of the descriptive analysis of the percentage of attendance at Hotel Muria Semarang can be seen in the following table:

Table 5 Results of Descriptive Calculation of Attendance Indicators

\begin{tabular}{cccc}
\hline No. & frequency & percentage & answer \\
\hline 1 & 1 & $1.89 \%$ & don't agree \\
2 & 36 & $67.92 \%$ & Sego \\
3 & 14 & $26.42 \%$ & Disagree \\
4 & 2 & $3.77 \%$ & Do not agree \\
5 & 0 & $0.00 \%$ & Sadon't agree \\
\hline Jumlah & 53 & $100 \%$ &
\end{tabular}

BeBased on the table above, the results of the attendance study were $67.92 \%$ agreed, based on the total attendance indicator score of 365 or $68.87 \%$, so attendance was included in the good category. It can be seen that some employees have good work attendance.

\section{abilitya Collaborate}

The ability to work together is the ability of a workforce to work together with other people in completing a task and work that has been set so as to achieve maximum usability and results. The results of the descriptive analysis of the percentage of ability to cooperate at Hotel Muria Semarang can be seen in the following table:

Table 6 Descriptive Calculation Results of the Ability to Cooperate

\begin{tabular}{cccc}
\hline No. & Frequency & percentage & answer \\
\hline 1 & 5 & $9.43 \%$ & Sadon't agree \\
2 & 38 & $71.70 \%$ & Sego \\
3 & 8 & $15.09 \%$ & Disagree \\
4 & 2 & $3.77 \%$ & Do not agree \\
5 & 0 & $0.00 \%$ & Sadon't agree \\
\hline Jumlah & 53 & $100 \%$ &
\end{tabular}

The Effect Of Motivation And Work Environment On The Performance Of Hotel Employees, Muria Semarang Arta Adi Kusuma 
BeBased on table 6 above, the results of the research on the ability to cooperate as much as $71.70 \%$ agree, based on the total score of the indicator of the ability to cooperate of 386 or $72.83 \%$, the ability to cooperate is included in the good category. Most employees can work well with others such as often coordinating with other employees in completing joint tasks so that work is also completed quickly.

\section{Mmotivation (X1)}

Motivation is the drive, desire, desire and driving force that comes from humans to do or to do something. So basically if the company wants to achieve optimal performance in accordance with the targets that have been set, the company must motivate employees so that employees are willing and willing to devote their energy and thoughts for the sake of work. The results of the descriptive analysis of the percentage of motivational variables at Hotel Muria Semarang can be seen in the following table:

Table 7 Results of Descriptive Calculation of Motivation Indicators

\begin{tabular}{cccc}
\hline No. & Ffrequency & Pepercentage & Jaanswer \\
\hline 1 & 4 & $7.55 \%$ & Sadon't agree \\
2 & 29 & $54.72 \%$ & Sego \\
3 & 18 & $33.96 \%$ & Disagree \\
4 & 2 & $3.77 \%$ & Do not agree \\
5 & 0 & $0.00 \%$ & Sadon't agree \\
\hline Jumlah & 53 & $100 \%$ &
\end{tabular}

BeBased on table 7 above, as much as $54.72 \%$ agree, based on the total score of the motivation variable of 2050 or $70.33 \%$, motivation is included in the good category. This is because most employees have good work motivation so that the resulting performance is also good.

\section{Garden Physiological}

Physiological needs are the most basic hierarchy of human needs which are the needs to be able to live such as eating, drinking, housing, oxygen, sleeping and so on. The results of the descriptive analysis of the percentage of physiological needs at Hotel Muria Semarang can be seen in the following table:

Table 8 Results of Descriptive Calculation of Physiological Needs Indicators

\begin{tabular}{cccc}
\hline No. & Ffrequency & Pepercentage & Jaanswer \\
\hline 1 & 7 & $13.21 \%$ & Sadon't agree \\
2 & 30 & $56.60 \%$ & Sego \\
3 & 10 & $18.87 \%$ & Disagree \\
4 & 5 & $9.43 \%$ & Do not agree \\
5 & 1 & $1.89 \%$ & Sadon't agree \\
\hline Jumlah & 53 & $100 \%$ &
\end{tabular}

BeBased on table 8 above, the results of the physiological needs study as much as $56.60 \%$ agreed, based on the total score of the physiological needs indicator of 379 or $71.51 \%$ so physiological needs were included in the good category. This is due to the fulfillment of housing needs such as clothing and some employees have fulfilled their food and drink needs.

\section{gardengod of security}

If the physiological needs are relatively satisfied, then a second need emerges, namely the need for security. The need for this sense of security includes security for protection from the dangers of work accidents, guarantees for the continuity of their work and guarantees for their old age when they are no longer working. The results of the descriptive analysis of the percentage of security needs at Hotel Muria Semarang can be seen in the following table:

Table 9 Results of Descriptive Calculation of Security Needs Indicators

\begin{tabular}{cccc}
\hline No. & Ffrequency & Pepercentage & Jaanswer \\
\hline 1 & 3 & $5.66 \%$ & Sadon't agree \\
2 & 24 & $45.28 \%$ & Sego \\
3 & 12 & $22.64 \%$ & Disagree \\
4 & 14 & $26.42 \%$ & Do not agree
\end{tabular}

The Effect Of Motivation And Work Environment On The Performance Of Hotel Employees, Muria Semarang Arta Adi Kusuma 


\begin{tabular}{cccc}
5 & 0 & $0.00 \%$ & Sadon't agree \\
\hline Jumlah & 53 & $100 \%$ &
\end{tabular}

Based on table 9 above, the results of the research on security needs as much as $45.28 \%$ agreed, based on the total score of the security needs indicator of 346 or $65.28 \%$ so the need for security was included in the fairly good category. It can be seen that most employees feel that their sense of security has been fulfilled, such as the existence of health and safety insurance guarantees. But some of the employees' sense of security has not been fulfilled, such as guarantees for a better future from the company.

\section{Garden Social}

When physiological and safety needs have been minimally satisfied, social needs emerge, namely the need for friendship, affiliation and closer interaction with others. In the organization it will be related to the need for a compact work group, good supervision, joint recreation and so on. The results of the descriptive analysis of the percentage of social needs at Hotel Muria Semarang can be seen in the following table:

Table 10 Results of Descriptive Calculation of Social Needs Indicators

\begin{tabular}{cccc}
\hline No. & Frequency & percentage & answer \\
\hline 1 & 3 & $5.66 \%$ & Sadon't agree \\
2 & 26 & $49.06 \%$ & Sego \\
3 & 7 & $13.21 \%$ & Disagree \\
4 & 15 & $28.30 \%$ & Do not agree \\
5 & 2 & $3.77 \%$ & Sadon't agree \\
\hline Jumlah & 53 & $100 \%$ &
\end{tabular}

Based on the table above, the results of the social needs research as much as $49.06 \%$ agree, based on the total score of the social needs indicator of 342 or $64.53 \%$ so that social needs are included in the fairly good category. Some employees have fulfilled social needs such as not being discriminated against between one employee and another, the existence of a compact work group, and interaction with co-workers in conversing, but there are also employees who do not interact with other employees.

\section{Garden Self Appreciation}

This need includes the need for the desire to be respected, to be appreciated for one's achievements, recognition of one's abilities and expertise and the effectiveness of one's work. The results of the descriptive analysis of the percentage of self-esteem needs at Hotel Muria Semarang can be seen in the following table:

Table 11 Results of Descriptive Calculation of Self-Esteem Indicators

\begin{tabular}{cccc}
\hline No. & Frequency & percentage & answer \\
\hline 1 & 2 & $3.77 \%$ & Sadon't agree \\
2 & 23 & $43.40 \%$ & Sego \\
3 & 22 & $41.51 \%$ & Disagree \\
4 & 5 & $9.43 \%$ & Do not agree \\
5 & 1 & $1.89 \%$ & Sadon't agree \\
\hline Jumlah & 53 & $100 \%$ &
\end{tabular}

Based on table 11 above, the results of the research on self-esteem needs as much as $43.40 \%$ agree, based on the total score of the self-esteem needs indicator of 541 or $68.05 \%$ so the need for self-esteem is included in the good category. As some have also fulfilled the need for self-esteem such as praise from superiors for satisfactory work.

\section{Self-Actualization Needs}

Self-actualization is the highest hierarchy of needs from Maslow. Self-actualization is related to the process of developing the true potential of a person. The need to demonstrate one's abilities, skills and potential. Even the need for self-actualization has a potential tendency to increase as people actualize their behavior. A person who is dominated by the need for self-actualization enjoys tasks that challenge his or her abilities and skills. The results of the descriptive analysis of the percentage of self-actualization needs at Hotel Muria Semarang can be seen in the following table:

Table 12: Descriptive Calculation Results of Self-Actualization Indicators 
http://ejournal.seaninstitute.or.id/index.php/Ekonomi

Jurnal Ekonomi, Volume 10, No 02 December 2021

ISSN: 2301-6280 (print) ISSN: 2721-9879 (online)

\begin{tabular}{cccc}
\hline No. & frequency & percentage & answer \\
\hline 1 & 21 & $39.62 \%$ & Sadon't agree \\
2 & 26 & $49.06 \%$ & Sego \\
3 & 3 & $5.66 \%$ & Disagree \\
4 & 3 & $5.66 \%$ & Do not agree \\
5 & 0 & $0.00 \%$ & Sadon't agree \\
\hline Jumlah & 53 & $100 \%$ &
\end{tabular}

Based on table 12 above, the results of the research on self-actualization needs as much as $49.06 \%$ agreed, based on the total score of indicators for self-actualization needs of 442 or $83.40 \%$, so self-actualization needs were included in the good category. There is freedom in expressing opinions/ideas/ideas.

Work Environment (X2)

According to Sedarmayanti (2001: 137) states that broadly speaking, the type of work environment is divided into 2, namely: (a) physical work environment, and (b) non-physical work environment. The physical work environment includes: lighting/light, air temperature/temperature, humidity, air circulation, noise, mechanical equivalence, unpleasant odors, colors, decorations, music and safety in the workplace. The results of descriptive analysis of the percentage of work environment variables at Hotel Muria Semarang can be seen in the following table:

Table 4.13: Descriptive Calculation Results of Work Environment Variables

\begin{tabular}{cccc}
\hline No. & Ffrequency & Pepercentage & Jaanswer \\
\hline 1 & 7 & $13.21 \%$ & Sadon't agree \\
2 & 29 & $54.72 \%$ & Sego \\
3 & 16 & $30.19 \%$ & Disagree \\
4 & 1 & $1.89 \%$ & Do not agree \\
5 & 0 & $0.00 \%$ & Sadon't agree \\
\hline Jumlah & 53 & $100 \%$ &
\end{tabular}

Based on table 13 above, the results of the work environment research as much as $54.72 \%$ agreed, based on the total score of the work environment variable of 2050 or $70.33 \%$ of the work environment included in the good category. Such as a comfortable working atmosphere, harmonious relations with co-workers, the availability of adequate work facilities, adequate lighting, the absence of unpleasant odors in the room, noise and well-maintained company security.

\section{Discussion}

Based on data analysis in this study, it can be seen that motivation has a significant influence on employee performance. This is shown from the partial test results obtained from the partial correlation coefficient of 0.347 so that $\mathrm{r} 2$ is $(0.347) 2=0.1204$ or $12.04 \%$, which means that the effective contribution to motivation on employee performance is $12.04 \%$. Partially, motivation affects the performance of Hotel Muria Semarang employees, because it is significantly smaller than 0.05 so that Ha which reads "there is an influence of motivation on employee performance at Hotel Muria Semarang" is accepted. This shows that with good motivation at work will get maximum employee performance while with less motivation will result in low employee performance. This is in accordance with the theory of Handoko (2001: 193) which states that motivation is one of the factors that can affect employee performance. Related to this opinion, someone who is motivated to work will produce optimal performance.

Based on the results of the study, it was found that there was a low indication of the motivation variable on the indicators of security and social needs. This condition can be seen from the respondents' answers to the need for security, namely the absence of a better future guarantee from the company and guarantees for work safety by some employees as well as from social needs, namely the lack of interaction between employees at work and the indifferent attitude between employees. It is hoped that the need for security can be overcome, such as with an old-age guarantee after the work period is over or a guarantee to be included in the Jamsostek program.

Besides motivation, the work environment also affects employee performance. Based on data analysis in this study, it can be seen that the work environment has a significant influence on employee performance. This is shown from the partial test results obtained from the partial correlation coefficient of 
0.298 so that $\mathrm{r} 2$ is $(0.298) 2=0.0888$ or $8.88 \%$ which means that the effective contribution to the work environment on employee performance is $8.88 \%$. Partially the work environment affects the performance of the employees of Hotel Muria Semarang, because it is significantly smaller than 0.05 so that Ha which reads "there is an influence of the work environment on the performance of the employees of Hotel Muria Semarang" is accepted. This shows that a good work environment will result in good employee performance, while a low work environment will result in low employee performance. This is in accordance with the theory of Nitisemito, (2000: 183) that a work environment condition can be said to be good if employees can carry out activities optimally, healthy, safe, and comfortable, while a poor work environment demands more labor and time. and does not support obtaining an efficient work system design. A conducive work environment can have a direct effect on employees in improving employee performance. On the other hand, an inadequate work environment will reduce employee performance.

The contribution of the work environment that has not had a big influence on the performance of the employees of Hotel Muria Semarang. This condition is based on the answer scores from respondents on lighting indicators in the workplace, namely that the lighting in the workplace is still inadequate and inadequate, it can be caused by improper installation of lights and blinding the eyes when working. The existence of lighting in the workplace can be overcome by installing lights in strategic places and not dazzling the eyes and adapted to workplace conditions so as not to dazzle the eyes when working, so that employees feel calm and comfortable at work.

The results showed that motivation and work environment had a significant effect on employee performance at Hotel Muria Semarang simultaneously or partially. The results of the simultaneous test data analysis show that motivation and work environment together have a significant influence on the employee performance of Hotel Muria Semarang by $37.6 \%$. Thus, it can be explained that in addition to motivation and work environment, employee performance is also determined by other factors not examined in this study, amounting to $62.4 \%$. The magnitude of this influence is small, because in addition to work motivation, there are many other factors that also affect employee performance. For example, even though the work environment is good but the level of concern for the environment is less, then employee performance can be less than optimal. Even though the work environment is good but not supported by other adequate facilities, employee performance can also be less than optimal. So that we can achieve maximum employee performance, then we must understand the factors that affect the performance of these employees. Employee performance will increase when the influencing factors influence in a harmonious and positive manner.

\section{CONCLUSION}

The conclusions that can be drawn from the results of research and discussion are as follows:

1. There is an effect of work motivation on employee performance at Hotel Muria Semarang, with a contribution of $12.04 \%$.

2. There is an influence of the work environment on the employee performance of Hotel Muria Semarang, with a contribution of $8.88 \%$.

3. There is an effect of work motivation and work environment together on the performance of Hotel Muria Semarang employees, with a contribution of $37.6 \%$, while the remaining $62.4 \%$ is influenced by other factors.

[1] "PENGARUH KEDISIPLINAN, LINGKUNGAN KERJA DAN BUDAYA KERJA TERHADAP KINERJA TENAGA PENGAJAR," J. Econ., vol. 9, no. 2, 2013, doi: 10.21831/economia.v9i2.1809.

[2] A. A. Suharto, "Pengaruh Kualitas Sumber Daya Manusia, KOmitmen Dan MOtivasi Terhadap Kinerja Pegawai Pada inspektorat kabupaten kediri," Ilmu Manaj., vol. 3, 2012.

[3] "ANALISIS KUALITAS KEHIDUPAN KERJA, KINERJA, DAN KEPUASAN KERJA PADA CV DUTA SENENAN JEPARA," J. Econ., vol. 8, no. 1, 2012, doi: 10.21831/economia.v8i1.797.

[4] Y. Suwati, "Pengaruh Kompensasi Dan Motivasi Kerja Terhadap Kinerja Karyawan Pada Pt. Tunas Hijau Samarinda," eJournal Ilmu Adm. Bisnis, vol. 1, no. 1, 2013.

[5] Heryansyah, S. Muhammad, and S. Syahnur, "Analisis Faktor-Faktor Yang Mempengaruhi Produksi Nelayan Di Kabupaten Aceh Timur," J. Ilmu Ekon. Pascasarj. Univ. Syiah Kuala, vol. 1, no. 2, 2013.

[6] Leonando Agsta and E. M. Sutanto, "Pengaruh Pelatihan Dan Motivasi Kerja Terhadap Kinerja Karyawan Cv Haragon Surabaya," Agora, vol. 1, no. 3, 2013.

[7] U. N. Yunarifah and L. Kustiani, "Pengaruh Motivasi Kerja Terhadap Kinerja Karyawan Pt. Kebon

The Effect Of Motivation And Work Environment On The Performance Of Hotel Employees, Muria Semarang Arta Adi Kusuma 
Agung Malang," Ekon. Mod., vol. 8, no. 2, 2012.

[8] I. Diatmika Paripurna, "PENGARUH KEPEMIMPINAN, LINGKUNGAN KERJA DAN KOMUNIKASI TERHADAP KEPUASAN KERJA KARYAWAN," E-Jurnal Manaj. Univ. Udayana, vol. 2, no. 5, 2013.

[9] D. K. Sofyan, "Pengaruh Lingkungan Kerja Terhadap Kinerja Kerja Pegawai BAPPEDA," Malikussaleh Ind. Eng., vol. 2, no. 1, 2013.

[10] I. Ayu Maya Prabasari and I. Salit Ketut Netra, "Pengaruh Motivasi, Disiplin Kerja Dan Komunikasi Terhadap Kinerja Karyawan Pada Pt. Pln (Persero) Distribusi Bali," E-Jurnal Manaj. Univ. Udayana, vol. 2, no. 4, 2013. 